\title{
Oxidative Stress Markers Patients with Parotid Gland Tumors: A Pilot Study
}

\author{
Pawel Sowa $\left(\mathbb{D},{ }^{1}\right.$ Maciej Misiolek, ${ }^{1}$ Bartlomiej Pasinski, ${ }^{2}$ Grzegorz Bartosz $\left(\mathbb{D},{ }^{2}\right.$ \\ Miroslaw Soszynski, ${ }^{2}$ Monika Adamczyk-Sowa, ${ }^{3}$ and Izabela Sadowska-Bartosz $\circledast^{4}$ \\ ${ }^{1}$ Department of Otorhinolaryngology and Laryngological Oncology in Zabrze, Medical University of Silesia, \\ Curie-Skłodowskiej St. 10, 41-800 Zabrze, Poland \\ ${ }^{2}$ Department of Molecular Biophysics, Faculty of Biology and Environmental Protection, University of Lodz, \\ Pomorska St. 141/143, 90-236 Lodz, Poland \\ ${ }^{3}$ Department of Neurology in Zabrze, Medical University of Silesia, 3-go Maja St. 13-15, 41-800 Zabrze, Poland \\ ${ }^{4}$ Department of Analytical Biochemistry, Faculty of Biology and Agriculture, University of Rzeszow, \\ Ul. Zelwerowicza 4, 35-601 Rzeszow, Poland
}

Correspondence should be addressed to Izabela Sadowska-Bartosz; isadowska@poczta.fm

Received 23 September 2017; Accepted 20 November 2017; Published 30 January 2018

Academic Editor: Kazim Husain

Copyright (C) 2018 Pawel Sowa et al. This is an open access article distributed under the Creative Commons Attribution License, which permits unrestricted use, distribution, and reproduction in any medium, provided the original work is properly cited.

\begin{abstract}
Salivary gland tumors account for 3-6\% of tumors of the head and neck. About $80 \%$ of salivary gland tumors occur in parotid glands. Oxidative stress (OS) is implicated in the origin, development, and whole-body effects of various tumors. There are no data on the occurrence of OS in the parotid gland tumors. The aim of this study was to ascertain if whole-body OS accompanies parotid gland tumors, based first of all on oxidative modifications of blood serum proteins and other markers of OS in the serum of the patients. The group studied included 17 patients with pleomorphic adenoma, 9 patients with Warthin's tumor, 8 patients with acinic cell carcinoma, and 24 age-matched controls. We found increased concentration of interleukin 4 in patients with acinic cell carcinoma, decreased plasma thiols, increased AOPP concentration, and decreased FRAP of blood serum in all groups of the patients while protein oxidative modifications assessed fluorimetrically, protein carbonyls, protein nitration, malondialdehyde concentration, and serum ABTS* ${ }^{*}$-scavenging capacity were unchanged. These data indicate the occurrence of OS in patients with parotid gland tumors and point to various sensitivities of OS markers.
\end{abstract}

\section{Introduction}

For the past 45 years or so, oxidative stress (OS) has been increasingly recognized as a contributing factor in aging as well as in various forms of pathophysiology such as tumors [1].

Salivary gland tumors account for 3-6\% of tumors of the head and neck. About $80 \%$ of salivary gland tumors occur in parotid glands, $10-17 \%$ of which are malignant [2]. The tumor is seen predominantly among white people, mainly between the 5th and 6th decade of life. Males suffer twice as often as females [3].

The parotid glands are the largest salivary glands in humans and are frequently involved in disease processes. Factors that increase the risk of parotid gland cancer include older age. In recent years, there has been a significant increase in the number of patients hospitalized and operated due to parotid salivary tumors. Over the past few years, in the Department of Otorhinolaryngology and Laryngological Oncology in Zabrze (Poland), we have been operating more than twice as many patients per year compared to previous years. Although some reports indicate possible use of cellular phones as an etiological factor [4-6], others deny such observations [7].

The vast majority of parotid salivary tumors are benign, with pleomorphic adenoma (PA, $60 \%$ of all benign salivary gland tumors) and Warthin's tumor (WT), also known as adenolymphoma or papillary lymphomatous cystadenoma (5-30\% of all salivary gland tumors) [8]. Pleomorphic adenoma is the most common benign mixed salivary gland 
neoplasm. It has diverse histological presentation and occurs in both major and minor salivary glands [9]. Warthin's tumor is more common in male patients (4:1 male: female ratio) during the sixth and seventh decades of life [10, 11]. Unlike other benign neoplasms of the salivary glands, this tumor has a tendency towards bilateral involvement, and approximately $90 \%$ of lesions occur in the superficial lobe of the parotid gland $[11,12]$.

Although malignant tumors in the salivary glands represent a definite minority (about 10\%), it is important to remember that some benign tumors may undergo malignant transformation (e.g., about 5\% of pleomorphic adenoma) [13]. Acinic cell carcinoma (ACC) of salivary gland represents $2.5 \%-5 \%$ of all parotid gland neoplasms [14]. Acinic cell carcinoma occurs in the parotid gland more often than primary planoepithelial carcinoma. In comparison to other salivary gland malignancies (adenoid cystic carcinoma or salivary duct carcinoma), ACC malignancy is quite low. This is reflected in the high level of 10-year survival rates (70\%) [3].

Oxidative stress is implicated in the origin, development, and whole-body effects of various tumors [15-17].

The most commonly used markers of OS include increased levels of oxidation products of lipids, proteins and nucleic acids and decreased concentrations of antioxidants. The blood serum concentration of malondialdehyde (MDA) is assayed most frequently, although this assay is often criticized due to its low specificity [18]. Among markers of protein oxidation, decreased protein thiol group content and increase of protein carbonyl content are most often determined. Since low-molecular thiols are very low in blood serum, serum thiol groups represent almost exclusively protein thiols [19]. Advanced Oxidation Protein Products (AOPP) have been proposed as another marker of protein oxidative damage [20]. We have used fluorimetric measurements to evaluate the increase in tryptophan and tyrosine oxidative degradation products, such as $\mathrm{N}$-formylkynurenine, kynurenine and dityrosine, and glycophore, the product of protein glycoxidation $[21,22]$. The nitrotyrosine content is a measure of protein modifications by reactive nitrogen species, mainly peroxynitrite [23]. Decreases in concentrations of individual antioxidants, for example, ascorbic acid, are sensitive indices of oxidative stress; another parameter evaluated in this respect is the total antioxidant capacity (TAC) of blood serum [24].

There are no data on the occurrence of OS in the parotid gland tumors. The aim of this study was to ascertain if wholebody OS accompanies parotid gland tumors, based first of all on oxidative modifications of blood serum proteins including protein thiol group level and AOPP and other markers of OS in the serum of the patients with parotid gland tumors such as total antioxidant activity (TAC) of the serum.

\section{Materials and Methods}

2.1. Patients with Salivary Gland Tumors and Study Design. The experiment was planned prospectively. Among all nonsmokers patients admitted to the Department of Otorhinolaryngology and Oncological Laryngology in Zabrze, Medical University of Silesia in Katowice, Poland, we selected those

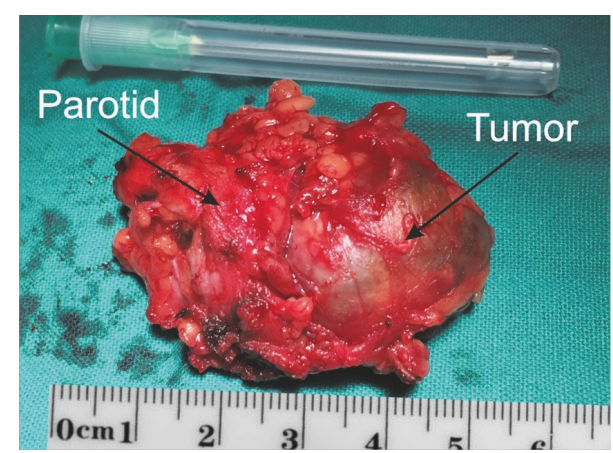

FIGURE 1: Pleomorphic adenoma of parotid gland: the intraoperative view after removing of the tumor (Tumor) together with a part of superior lobe of parotid glad (Parotid).

suffering from parotid gland tumor at the turn of 2016 and 2017; thus we initially examined 86 individuals. Patients with previous oncological treatment, diabetes mellitus, or obesity were excluded from the study. We further examined 36 of those patients. Venous blood samples ( $5 \mathrm{ml}$ each) were taken, centrifuged, frozen, and stored in $-80^{\circ} \mathrm{C}$ until the final examination. Selected patients were divided into groups according to the postsurgical pathological results. Therefore we included 17 patients into pleomorphic adenoma (PA) group (Figure 1), 9 of them into Warthin's tumor (WT) group, and 8 into acinic cell carcinoma (ACC) group. Control group consisted of 24 age-matched healthy subjects. The remaining patients were excluded from experiment because of not clear pathological result or because of too small number of individuals to create a separate group.

The basic demographic and clinical characteristics of parotid cancer patients are summarized in Table 1. A preoperative fine-needle aspiration biopsy and ultrasonography were performed routinely in all patients. A superficial parotid lobectomy was performed when the tumor was located in the superficial lobe of the parotid gland. In cases with involvement of the deep lobe, total parotidectomy was performed. The term parotidectomy should be used when two conditions are fulfilled: dissection of the facial nerve (at least the main trunk and one the two major divisions) and removal of at least one level (Figure 2). Patients were operated by the same surgeon. Parotidectomy remains the mainstay of treatment for both benign and malignant lesions of the parotid gland. There exists a wide range of possible surgical options in parotidectomy in terms of extent of parotid tissue removed. Parotidectomies levels were graded according to the European Salivary Gland Society (ESGS) classification as follows: (I) lateral superior, (II) lateral inferior, (III) deep inferior, (IV) deep superior, and (V) accessory. The type of resection is divided into formal parotidectomy with facial nerve dissection and extracapsular dissection [25].

2.2. Materials. All basic reagents were from Sigma-Aldrich (Poznań, Poland), unless indicated otherwise. OxiSelect ${ }^{\mathrm{TM}}$ Protein Carbonyl Fluorometric Assay Kit (STA-310) was obtained from Cell Biolaboratories. 3-Nitrotyrosine in the proteins of human serum was determined by an ELISA 
TABLE 1: Demographic characteristics of the examined groups.

\begin{tabular}{|c|c|c|c|c|}
\hline Examined groups & Control $(n=24)$ & $\mathrm{PA}(n=17)$ & $\mathrm{WT}(n=9)$ & $\operatorname{ACC}(n=8)$ \\
\hline Age (years $\pm S D)$ & $55.5 \pm 9.4$ & $53.6 \pm 7.7$ & $57.4 \pm 6.8$ & $61.5 \pm 5.4$ \\
\hline Female/male & $16 / 8$ & $12 / 5$ & $5 / 4$ & $6 / 2$ \\
\hline \multicolumn{5}{|l|}{ Surgery type } \\
\hline ECD & & 1 & 0 & 0 \\
\hline Par I or II & & 3 & 4 & 0 \\
\hline Par I-II & NA & 9 & 1 & 1 \\
\hline Par I-III & & 2 & 2 & 0 \\
\hline Par I-IV & & 0 & 0 & 3 \\
\hline Mean tumor size $(\mathrm{mm})(\min -\max )$ & NA & $26(13-55)$ & $25(12-40)$ & $24(18-30)$ \\
\hline Tumor side, right/left & NA & $11 / 4$ & $4 / 3$ & $2 / 2$ \\
\hline
\end{tabular}

PA: pleomorphic adenoma group; WT: Warthin's tumor group; ACC: acinic cell carcinoma group; ECD: extra-capsular dissection; Par: parotidectomy; NA: nonapplicable.

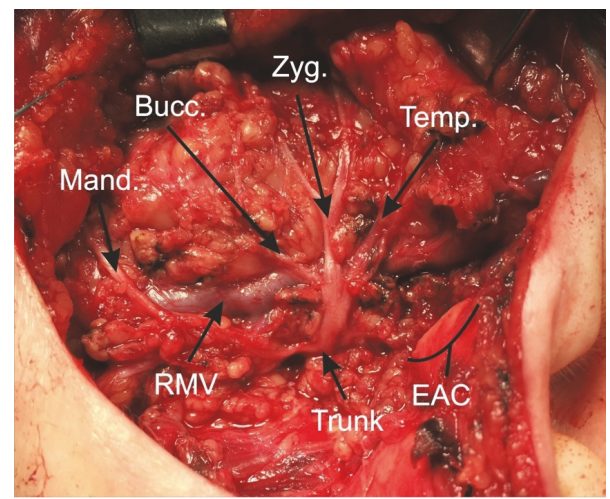

Figure 2: Surgical view of the left facial nerve (n. VII) after removal of the tumor and superficial lobe of the parotid gland. The main trunk (Trunk) of the nerve and its main branches: temporal (Temp.), zygomatic (Zyg.), buccal (Bucc.), and mandibular (Mand.) were marked by arrows. Cartilage of external auditory canal was marked as EAC and retromandibular vein as RMV.

method (Catalog\# K7829; Immundiagnostik AG, Bensheim, Germany). Human IL-4 Quantikine ELISA Kit (Catalog\# D4050) was purchased from R\&D System (Minneapolis, MN, USA). Salivary $\alpha$-amylase activity was assayed using an Amylase Activity Colorimetric Assay Kit (Catalog\# K711-100; BioVision).

Fluorimetric and absorptiometric measurements were done in a Tecan Infinite 200 PRO multimode reader (Tecan Group Ltd., Männedorf, Switzerland) or in an EnVision Multilabel Plate Reader (Perkin-Elmer, Überlingen, Germany). All measurements were performed in triplicate and repeated a minimum of three times.

2.3. Blood Sampling. Samples of venous blood $(5 \mathrm{ml})$ from tumor-bearing untreated patients (before surgery) and controls were collected into serum-separating tubes and immediately centrifuged to isolate serum. Collected serum samples were stored at $-80^{\circ} \mathrm{C}$ until biochemical analysis, for no more than 2 months. They were thawed at room temperature only once at the time of analysis.
2.4. Determination of $\alpha$-Amylase Activity. The $\alpha$-amylase activity was determined using the Amylase Activity Colorimetric Assay Kit (BioVision) according to the instruction of the manufacturer.

2.5. Estimation of Interleukin 4 Concentration. Serum IL-4 concentration was estimated by an enzyme immunoassay (ELISA) using Quantikine Human IL-4 Diagnostics Kit.

2.6. Estimation of Protein Carbonyls and Protein Nitration. The content of protein carbonyls and protein 3-nitrotyrosine were estimated using OxiSelect ${ }^{\mathrm{TM}}$ Protein Carbonyl Fluorometric Assay Kit and 3-Nitrotyrosine ELISA kit, respectively, according to the protocols supplied by the manufacturers.

2.7. Estimation of Protein Oxidative Modifications. Products of oxidative modifications of proteins were estimated on the basis of their characteristic fluorescence. Fluorescence measurements were done by applying $150 \mu \mathrm{l}$ of the serum diluted 1:50 with phosphate-buffered saline (PBS; 1 tablet of $\mathrm{PBS} / 100 \mathrm{ml} \mathrm{H}_{2} \mathrm{O}$ ) on wells of a 96well plate. Fluorescence was measured at wavelengths of 325/440 (AGEs), 330/415 (dityrosine), 325/434 ( $\mathrm{N}^{\prime}$-formylkynurenine), 365/480 (kynurenine), and 295/340 nm (tryptophan) [21, 22].

2.8. Estimation of Thiol Groups. Thiol groups were estimated using a modification of the Ellman's method [26]. Samples $(20 \mu \mathrm{l})$ were pipetted to wells of a 96 -well plate containing $100 \mu \mathrm{l}$ of $0.1 \mathrm{M}$ phosphate buffer, $\mathrm{pH}$ 8.0. Afterwards, $2 \mu \mathrm{l}$ of $10 \mathrm{mg} / \mathrm{ml}$ Ellman's reagent [5,5'-dithiobis-(2-nitrobenzoic acid); DTNB] was added. Absorbance was measured after $1 \mathrm{~h}$ incubation in the dark at $37^{\circ} \mathrm{C}$ at the wavelength of $412 \mathrm{~nm}$ against a reagent blank. The thiol group content was calculated on the basis of a standard curve using glutathione as a standard.

2.9. Estimation of Protein. The protein concentration was estimated using the method of Lowry et al. [27]. Serum diluted 200 times with PBS $(100 \mu \mathrm{l})$ was mixed with $500 \mu \mathrm{l}$ of 
the Lowry reagent (formed by mixing $30 \mathrm{ml}$ of $2 \% \mathrm{Na}_{2} \mathrm{CO}_{3}$ in $0.1 \mathrm{M} \mathrm{NaOH}, 0.6 \mathrm{ml}$ of $5 \% \mathrm{C}_{4} \mathrm{H}_{4} \mathrm{O}_{6} \mathrm{KNa} \cdot 4 \mathrm{H}_{2} \mathrm{O}$, and $0.6 \mathrm{ml}$ of $2 \% \mathrm{Cu}_{2} \mathrm{SO}_{4}$ ) and incubated at room temperature for $10 \mathrm{~min}$. Afterwards, $50 \mu \mathrm{l}$ of the Folin-Ciocalteu reagent was added, and the plate was shaken and incubated at room temperature for $30 \mathrm{~min}$. The absorbance was measured at $750 \mathrm{~nm}$. Standard curve was prepared with human serum albumin $(0-300 \mu \mathrm{g} / \mathrm{ml})$.

2.10. Estimation of Malondialdehyde (MDA). Serum MDA concentration was assayed according to Ohkawa et al. [28]. Briefly, the serum samples ( $50 \mu \mathrm{l}$ serum plus $50 \mu \mathrm{l}$ PBS or $100 \mu \mathrm{l}$ PBS blank) were mixed with $200 \mu \mathrm{l}$ of ice-cold mixture of $0.37 \%$ thiobarbituric acid (TBA) and $15 \%$ trichloroacetic acid (TCA) in $\mathrm{HCl}$ to precipitate protein. The reaction was performed at $\mathrm{pH} 2-3$ at $100^{\circ} \mathrm{C}$ for $40 \mathrm{~min}$. The precipitate was pelleted by centrifugation at $3000 \times \mathrm{g}$ at $4^{\circ} \mathrm{C}$ for $10 \mathrm{~min}$. Absorbance of the supernatants was read at a wavelength of $532 \mathrm{~nm}$.

The majority of TBA-reactive substances (TBARS) is MDA; thus the concentration of MDA in blood plasma was expressed in $\mu \mathrm{M}$. The results were calculated using an absorption coefficient for MDA of $1.56 \times 10^{5} \mathrm{M}^{-1} \mathrm{~cm}^{-1}$

2.11. Estimation of AOPP. Advanced oxidation protein products (AOPP) were estimated using the method of WitkoSarsat et al. [20]. Briefly, $200 \mu \mathrm{l}$ of serum diluted 1:5 with PBS was applied to the 96-well plate and $20 \mu \mathrm{l}$ of acetic acid was added to each well. Absorbance was measured at $340 \mathrm{~nm}$ against a blank containing $200 \mu \mathrm{l}$ of PBS, $20 \mu \mathrm{l}$ of acetic acid, and $10 \mu \mathrm{l}$ of $1.16 \mathrm{M}$ potassium iodide. Calibration curve was prepared using chloramine $\mathrm{T}$ at concentrations of $0-100 \mu \mathrm{M}$ by applying $200 \mu \mathrm{l}$ chloramine T, $20 \mu \mathrm{l}$ acetic acid, and $10 \mu \mathrm{l}$ of $1.16 \mathrm{M}$ potassium iodide to the plate. AOPP concentration is expressed in nmol chloramine T-equivalents/mg protein.

\subsection{Estimation of Total Antioxidant Capacity of Blood Serum} as FRAP. The serum a total antioxidant status was measured in serum using the ferric reducing antioxidant power assay (FRAP). The Ferric Reducing Antioxidant Potential assay measures the ability of antioxidants to reduce ferric $\left(\mathrm{Fe}^{3+}\right)$ ions to ferrous $\left(\mathrm{Fe}^{2+}\right)$ ions [29]. $0.3 \mathrm{M}$ acetate buffer $(\mathrm{pH}=$ 3.6), 0.01 M TPTZ (2,4,6-tripyridyl-s-triazine) in $0.04 \mathrm{M} \mathrm{HCl}$, and $0.02 \mathrm{M} \mathrm{FeCl}_{3} * 6 \mathrm{H}_{2} \mathrm{O}$ mixed in $10: 1: 1$ and $180 \mu \mathrm{l}$ of this mixture were added on wells of a 96-well plate containing $10 \mu \mathrm{l}$ of sample and $10 \mu \mathrm{l}$ of PBS. The reduction of $\mathrm{Fe}^{3+}-2,4,6-$ tripyridyl-s-triazine complex to the ferrous form at low $\mathrm{pH}$ was monitored by measuring the absorption change after $20 \mathrm{~min}$ incubation in room temperature at $593 \mathrm{~nm}$. The value was calculated relevant to the activity of Trolox and expressed as $\mu$ moles Trolox equivalents $/ \mathrm{l}(\mu \mathrm{M})$.

2.13. Estimation of Total Antioxidant Capacity with ABTS* Antiradical activity is a measure of the ability of a given compound to react with free radicals. One stable free radical employed in such reactions is the $2,2^{\prime}$-azinobis (3-ethylbenzothiazoline-6-sulfonic acid) radical (ABTS*). Standard antioxidants react rapidly with ABTS* $^{*}$ (within

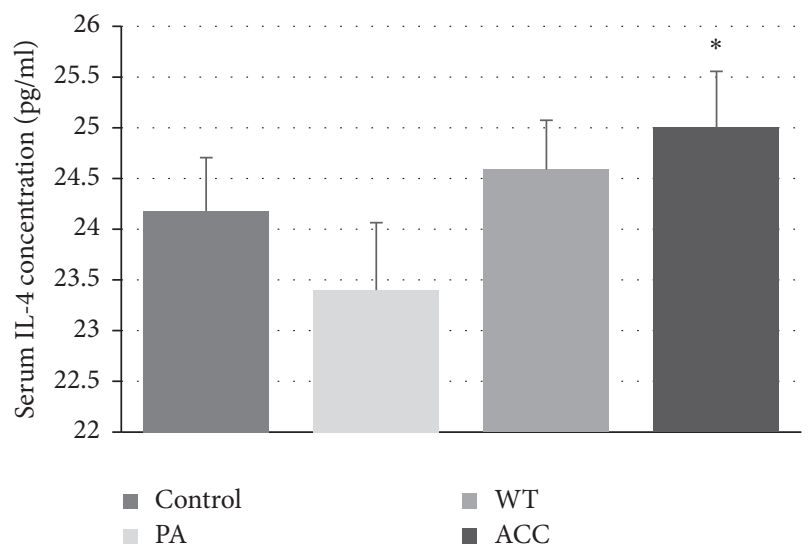

FIgURE 3: Serum IL-4 concentration in patients with parotid gland tumors; ${ }^{*} P<0.05$.

seconds; "fast antioxidants") while some react at a lower rate ("slow antioxidants") [24]. Briefly, $2 \mu \mathrm{l}$ of sample and $18 \mu \mathrm{l}$ of PBS were added to a solution of ABTS*, diluted, such that $200 \mu \mathrm{l}$ of the solution had absorbance of 1.0 in a microplate well. The decrease in ABTS* absorbance was measured after 1 min ("fast" scavenging) and between 10 and 30 min ("slow" scavenging) of incubation at ambient temperature $\left(21 \pm 1^{\circ} \mathrm{C}\right)$ at $414 \mathrm{~nm}$. FRAP value was calculated relevant to the activity of Trolox and expressed as $\mu$ moles Trolox equivalents $/ \mathrm{l}(\mu \mathrm{M})$.

2.14. Statistical Analysis. All experiments were performed at least in triplicate. Data are shown in the form of arithmetic mean values and standard deviations. Differences between means were analyzed using Kruskal-Wallis test. The statistical analysis of the data was performed using STATISTICA, version 12.5, (StatSoft, Inc., http://www.statsoft.com).

\section{Results and Discussion}

Serum amylase activity, expected to be altered in the patients, did not show consistent changes in patients with parotid gland tumors. There was a tendency for decrease in the WT and, especially, in the PA groups but they did not reach the level of statistical significance due to high interindividual variability (not shown).

Serum IL-4 concentration changed differently in different groups of parotid tumor patients, having a tendency for decrease in PA patients (not reaching statistical significance), not changing in WT patients and increasing in ACC patients (Figure 3). As IL-4 is involved in the stimulation of activated $\mathrm{B}$-cell and T-cell proliferation and the differentiation of $\mathrm{B}$ cells into plasma cells [30], the increase of its level in ACC patients points to changes in the immune system induced by the carcinoma. Il-4 has been demonstrated to suppress the development of tumor development in an atopic melanoma model [31] so the observed elevation of IL-4 level in ACC may reflect the attempt of the organism to combat the tumor.

Fluorimetric parameters of protein glycoxidation (tryptophan fluorescence, the levels of glycophore, dityrosine, Nformylkynurenine, and kynurenine) were not significantly 


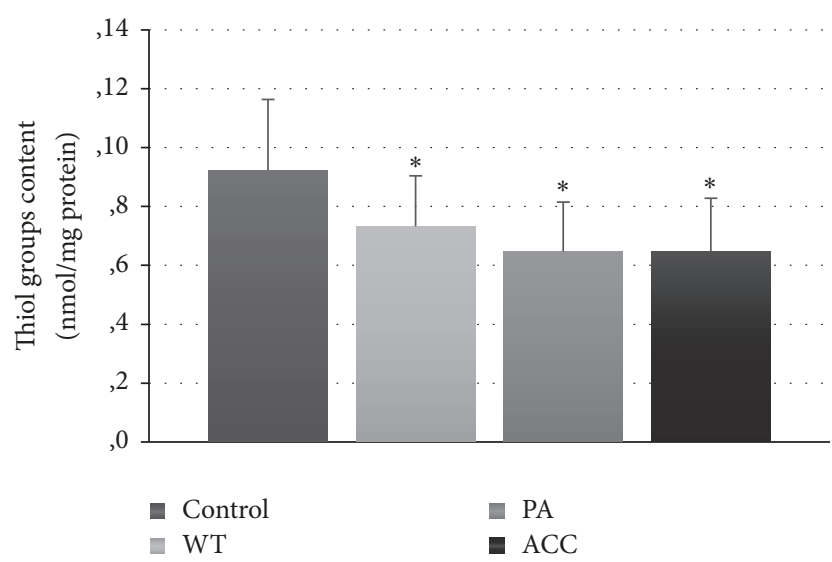

FIGURE 4: Serum thiol group content in patients with parotid gland tumors; ${ }^{*} P<0.05$.

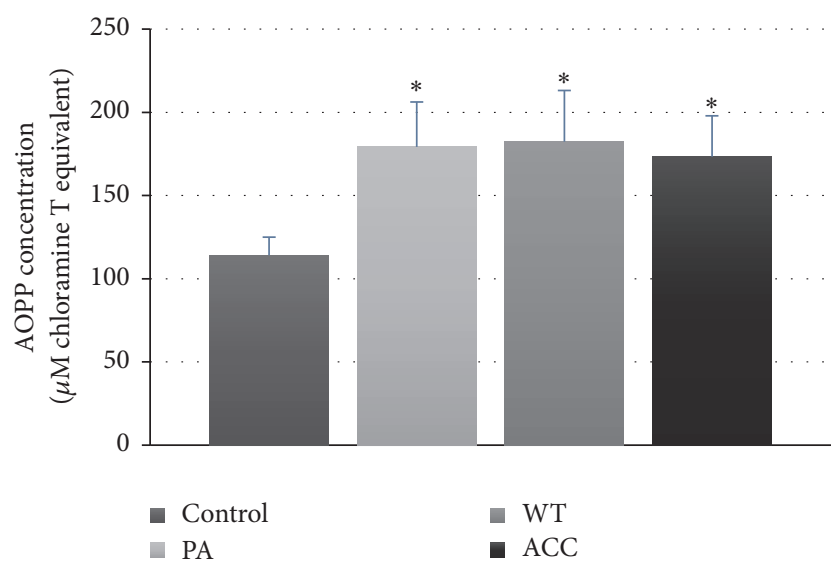

FIGURE 5: Serum AOPP concentration in patients with parotid gland tumors; ${ }^{*} P<0.05$.

altered with respect to the control groups (not shown). However, the level of thiol groups decreased (Figure 4) and the AOPP level was elevated (Figure 5) in all groups of parotid tumor patients.

Most of total blood plasma proteins are protein thiols (400-600 $\mu \mathrm{M})$, predominantly Cys 34 of serum albumin, which is reduced in about $75 \%$, while low-molecular weight thiols constitute only $12-20 \mu \mathrm{M}$. Plasma protein thiols react nonenzymatically with various reactive oxygen species so their level is decreased under OS conditions [19].

AOPPs are the dityrosine-containing and crosslinking protein products formed during OS by reaction of plasma protein with chlorinated oxidants and often carried by albumin in vivo. Accumulation of plasma and renal AOPPs is a common pathologic finding in chronic kidney disease patients but is also implicated in the pathogenesis of atherosclerosis and cardiovascular events [32]. The present results demonstrate that they may be a useful marker of OS also in other diseases.

The level of protein carbonyls and protein nitrotyrosine was not significantly altered with respect to the control group. Protein carbonyls had a tendency to increase in the

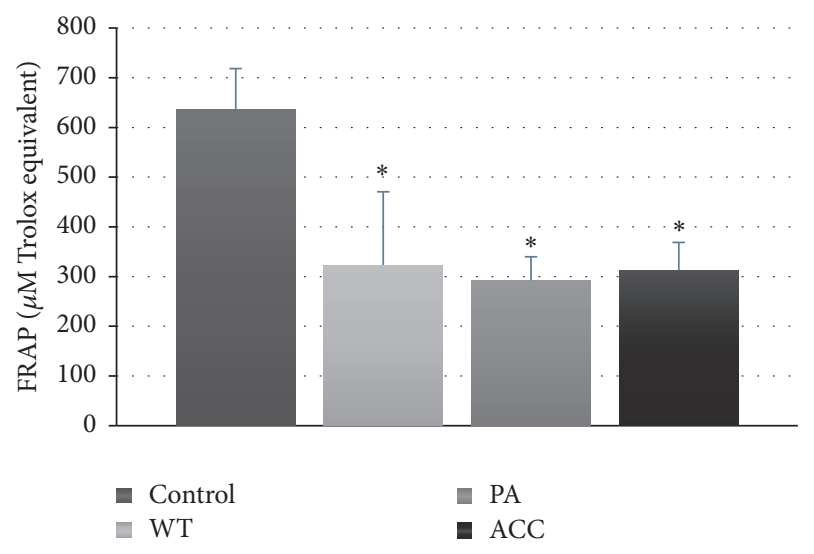

FIGURE 6: Serum FRAP in patients with parotid gland tumors; ${ }^{*} P<$ 0.05 .

PA group (not shown) while the nitrotyrosine level had a tendency to decrease in the PA and WT groups (not shown) but these changes were devoid of statistical significance. Interestingly, when data for males and females were evaluated independently, statistically significant differences were noted in the level of carbonyls in the WT group (females versus males: $0.73 \pm 0.16$ versus $0.47 \pm 0.07$ arbitrary units $(\mathrm{au})$, $P<0.05)$, in the PA group $(0.76 \pm 0.14$ versus $0.53 \pm 0.22$ au, $P<0.05)$, and in the ACC group in the level of nitrotyrosine ( $3.67 \pm 0.78$ versus $1.89 \pm 1.11 \mathrm{au})$. There were no significant differences in any parameters between the controls. In the case of the PA group, the carbonyl level was significantly elevated $(P<0.05)$ with respect to the control $(0.76 \pm 0.14$ versus $0.66 \pm 0.19$ au, $P<0.05)$. These data suggest that the level of OS is higher in females than in males in parotid cancer patients.

These data demonstrate whole-body oxidative stress patients with all parotid gland tumor patients studied but various parameters of oxidative protein modifications are not equally sensitive to detect it, the most sensitive being the protein thiol level and AOPP.

Other oxidative stress markers studied included serum MDA concentration and total antioxidant capacity (TAC) of the serum measured as TRAP and ABTS ${ }^{*}$ scavenging capacity. Although MDA concentration had a tendency to increase in the PA and WT groups and a tendency to decrease in the ACC groups, the differences measured did not reach statistical significance (not shown). Both "fast" and "slow" ABTS* scavenging capacity of blood serum of the patients were unchanged with respect to control (not shown). However, FRAP was decreased in all groups of patients studied (Figure 6). The difference between the results of TAC of blood serum by ABTS* scavenging and FRAP methods is striking. However, it should be taken into account that antioxidants present in serum differently contribute to results of TAC measurements by both methods. Uric acid contributes in $61.7 \%$ to the FRAP assay and only in $19.3 \%$ to results of ABTS-based assays, and the contribution of tocopherol is 5.8 and $1.7 \%$, respectively, that of ascorbic acid 10.1 and $3.1 \%$, respectively, and that of bilirubin 4.3 and 
$1.0 \%$, respectively [33]. It is still unclear why decrease in protein thiols is not reflected in decreased ABTS* ${ }^{*}$ scavenging capacity of blood serum of the patients, but albumin (mainly albumin thiols) contributes in only $28 \%$ to the ABTS* scavenging capacity of blood serum while other antioxidants are responsible for $46.9 \%$ of this capacity and increase in the level(s) of some of them might have contributed to the result obtained. What concerns FRAP, the decrease in protein thiols had to contribute to its decreased value but, since FRAP is dependent on albumin only in 7.3\% [33], decreased concentrations of other antioxidants had to have its share in decreased FRAP values in the patients. In any case, FRAP, previously documented to be decreased in many diseases involving oxidative stress [24], is sensitive enough to detect whole-body oxidative stress in patients with parotid gland tumors.

While the level of IL-4 was different on various patient groups, alterations in parameters reflecting OS were similar in all groups, which suggests that the level of OS is the same in all groups of parotid cancer patients.

In summary, the present results demonstrate the occurrence of whole-body oxidative stress parotid gland tumor patients like in many other types of tumor [15-17]. However, the intensity of whole-body oxidative stress in tumor of the parotid gland is relatively low as only some markers of oxidative stress (protein thiols, AOPP, and FRAP) evidence its occurrence. Taking into account the organ affected, it seems that studies of oxidative markers in saliva could be more promising. Such a study is in progress.

\section{Abbreviations}

ABTS*: 2,2'-Azinobis(3-ethylbenzothiazoline-6-sulfonic acid) free radical

ACC: Acinic cell carcinoma

AOPP: Advanced oxidation protein products

FRAP: Ferric Reducing Antioxidant Potential

MDA: Malondialdehyde

OS: Oxidative stress

PA: $\quad$ Pleomorphic adenoma

PBS: $\quad$ Phosphate-buffered saline

WT: Warthin's tumor.

\section{Ethical Approval}

The experimental protocol was approved by local ethical committee of the Medical University of Silesia in Katowice (nos. KNW/022/KB1/106/16 and KNW/022/KB1/106/I/16/17).

\section{Consent}

Informed consent was obtained from each patient prior to entry into the study, according to the declaration of Helsinki.

\section{Conflicts of Interest}

The authors claim that there are no conflicts of interest in this work.

\section{Acknowledgments}

The authors are indebted to Edyta Bieszczad-Bedrejczuk, M.S., for her technical help.

\section{References}

[1] B. M. Hybertson, B. Gao, S. K. Bose, and J. M. McCord, "Oxidative stress in health and disease: the therapeutic potential of Nrf2 activation," Molecular Aspects of Medicine, vol. 32, no. 4-6, pp. 234-246, 2011.

[2] G. Stryjewska-Makuch, B. Kolebacz, M. A. Janik, and A. Wolnik, "Increase in the incidence of parotid gland tumors in the years 2005-2014," Otolaryngologia Polska, vol. 71, no. 2, pp. 29-34, 2017.

[3] D. R. Gnepp, J. D. Henley, R. H. W. Simpson, and J. Eveson, "Salivary and lacrimal glands," Diagnostic Surgical Pathology of the Head and Neck, pp. 413-562, 2009.

[4] Y. Duan, H. Z. Zhang, and R. F. Bu, "Correlation between cellular phone use and epithelial parotid gland malignancies," International Journal of Oral and Maxillofacial Surgery, vol. 40, no. 9, pp. 966-972, 2011.

[5] S. Sadetzki, A. Chetrit, A. Jarus-Hakak et al., "Cellular phone use and risk of benign and malignant parotid gland tumors-a nationwide case-control study," American Journal of Epidemiology, vol. 167, no. 4, pp. 457-467, 2008.

[6] K. Al-Qahtani, "mobile phone use and the risk of parotid gland tumors: a retrospective case-control study," Gulf Journal of Oncology, vol. 1, no. 20, pp. 71-78, 2016.

[7] S. Lönn, A. Ahlbom, H. C. Christensen et al., "Mobile phone use and risk of parotid gland tumor," American Journal of Epidemiology, vol. 164, no. 7, pp. 637-643, 2006.

[8] R. Lau, A. Fernández-Coello, N. Vidal-Sarró et al., "Brain metastasis of carcinoma ex pleomorphic adenoma of the parotid gland: case report and review of the literature," Acta Neurochirurgica, vol. 159, no. 3, pp. 459-463, 2017.

[9] M. Hmidi, H. Aatifi, A. Boukhari, M. Zalagh, and A. Messary, "Pleomorphic adenoma of the soft palate: major tumor in a minor gland," Pan African Medical Journal, vol. 22, 2015.

[10] G. H. Yoo, D. W. Eisele, F. B. Askin, J. S. Driben, and M. E. Johns, "Warthin's tumor: a 40-year experience at the johns hopkins hospital," The Laryngoscope, vol. 104, no. 7, pp. 799-803, 1994.

[11] T. C. Chulam, A. L. Noronha Francisco, J. Goncalves Filho, C. A. Pinto Alves, and L. P. Kowalski, "Warthin's tumour of the parotid gland: Our experience," Acta Otorinorhinolaryngologica Italica, vol. 33, no. 6, pp. 393-397, 2013.

[12] T. Thangarajah, V. M. Reddy, F. Castellanos-Arango, and A. Panarese, "Current controversies in the management of Warthin tumour," Postgraduate Medical Journal, vol. 85, no. 999, pp. 3-8, 2009.

[13] L. Barnes, J. W. Eveson, P. Reichart et al., Pathology and Genetics of Head and Neck Tumours, vol. 9, WHO Classification of Tumours, 3rd edition, 2005.

[14] S. S. Al-Otaibi, F. Alotaibi, Y. Al Zaher, N. Al Zaher, and M. A. Dababo, "High-grade transformation (Dedifferentiation) of acinic cell carcinoma of the parotid gland: report of an unusual variant," Case Reports in Otolaryngology, vol. 2017, pp. 1-4, 2017.

[15] P. Deshmukh, S. Unni, G. Krishnappa, and B. Padmanabhan, "The Keap1-Nrf2 pathway: promising therapeutic target to counteract ROS-mediated damage in cancers and neurodegenerative diseases," Biophysical Reviews, vol. 9, no. 1, pp. 41-56, 2017. 
[16] J. Martinez-Useros, W. Li, M. Cabeza-Morales, and J. GarciaFoncillas, "Oxidative stress: a new target for pancreatic cancer prognosis and treatment," Journal of Clinical Medicine, vol. 6, no. 3, p. 29, 2017.

[17] J. Morry, W. Ngamcherdtrakul, and W. Yantasee, "Oxidative stress in cancer and fibrosis: opportunity for therapeutic intervention with antioxidant compounds, enzymes, and nanoparticles," Redox Biology, vol. 11, pp. 240-253, 2017.

[18] J. Frijhoff, P. G. Winyard, N. Zarkovic et al., "Clinical relevance of biomarkers of oxidative stress," Antioxidants \& Redox Signaling, vol. 23, no. 14, pp. 1144-1170, 2015.

[19] L. Turell, R. Radi, and B. Alvarez, "The thiol pool in human plasma: the central contribution of albumin to redox processes," Free Radical Biology \& Medicine, vol. 65, pp. 244-253, 2013.

[20] V. Witko-Sarsat, M. Friedlander, C. Capeillère-Blandin et al., "Advanced oxidation protein products as a novel marker of oxidative stress in uremia," Kidney International, vol. 49, no. 5, pp. 1304-1313, 1996.

[21] I. Sadowska-Bartosz, M. Adamczyk-Sowa, S. Galiniak, S. Mucha, K. Pierzchala, and G. Bartosz, "Oxidative modification of serum proteins in multiple sclerosis," Neurochemistry International, vol. 63, no. 5, pp. 507-516, 2013.

[22] I. Sadowska-Bartosz, M. Adamczyk-Sowa, A. Gajewska, and G. Bartosz, "Oxidative modification of blood serum proteins in multiple sclerosis after interferon or mitoxantrone treatment," Journal of Neuroimmunology, vol. 266, no. 1-2, pp. 67-74, 2014.

[23] M. B. Feeney and C. Schöneich, "Proteomic approaches to analyze protein tyrosine nitration," Antioxidants \& Redox Signaling, vol. 19, no. 11, pp. 1247-1256, 2013.

[24] G. Bartosz, "Total antioxidant capacity," in Advances in Clinical Chemistry Volume 37, vol. 37 of Advances in Clinical Chemistry, pp. 219-292, Elsevier, 2003.

[25] M. Quer, "Reply to the letter to the editor concerning: "classification of parotidectomies: a proposal of the european salivary gland society",' European Archives of Oto-Rhino-Laryngology, vol. 273, no. 10, p. 3453, 2016.

[26] G. L. Ellman, “Tissue sulfhydryl groups," Archives of Biochemistry and Biophysics, vol. 82, no. 1, pp. 70-77, 1959.

[27] O. H. Lowry, N. J. Rosebrough, A. L. Farr, and R. J. Randall, "Protein measurement with the Folin phenol reagent," Journal of Biological Chemistry, vol. 193, no. 1, pp. 265-275, 1951.

[28] H. Ohkawa, N. Ohishi, and K. Yagi, "Assay for lipid peroxides in animal tissues by thiobarbituric acid reaction," Analytical Biochemistry, vol. 95, no. 2, pp. 351-358, 1979.

[29] I. F. F. Benzie and J. J. Strain, "The ferric reducing ability of plasma (FRAP) as a measure of 'antioxidant power': the FRAP assay," Analytical Biochemistry, vol. 239, no. 1, pp. 70-76, 1996.

[30] W. E. Paul, "History of interleukin-4," Cytokine, vol. 75, no. 1, pp. 3-7, 2015.

[31] D. J. Son, Y. Y. Jung, M. H. Park et al., "Activated natural killer cells mediate the suppressive effect of interleukin- 4 on tumor development via STAT6 activation in an atopic condition melanoma model," Neoplasia, vol. 19, no. 7, pp. 537-548, 2017.

[32] W. Cao, F. F. Hou, and J. Nie, "AOPPs and the progression of kidney disease," Kidney International Supplements, vol. 4, no. 1, pp. 102-106, 2014.

[33] G. Cao and RL. Prior, "Comparison of different analytical methods for assessing total antioxidant capacity of human serum," Clinical Chemistry, vol. 44, pp. 1309-1315, 1998. 


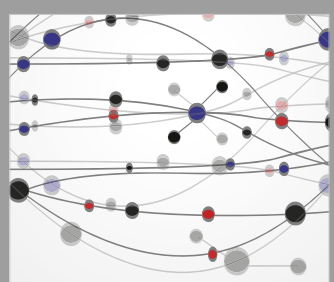

The Scientific World Journal
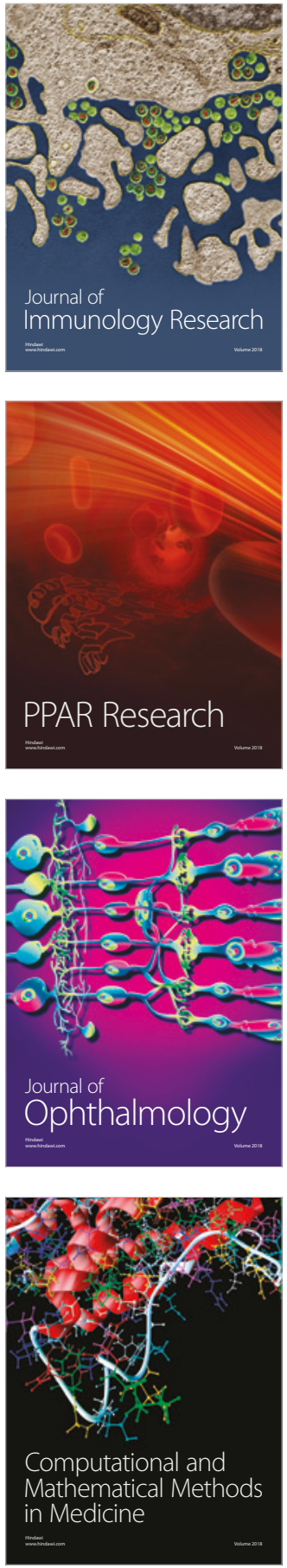

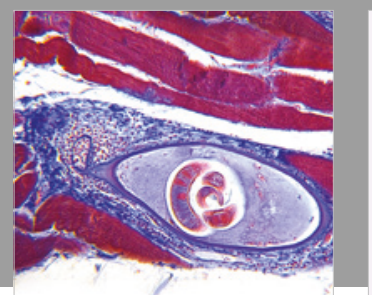

Gastroenterology Research and Practice

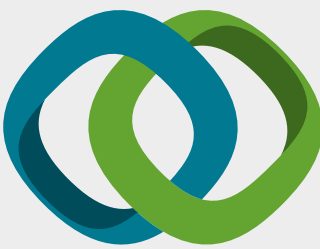

\section{Hindawi}

Submit your manuscripts at

www.hindawi.com
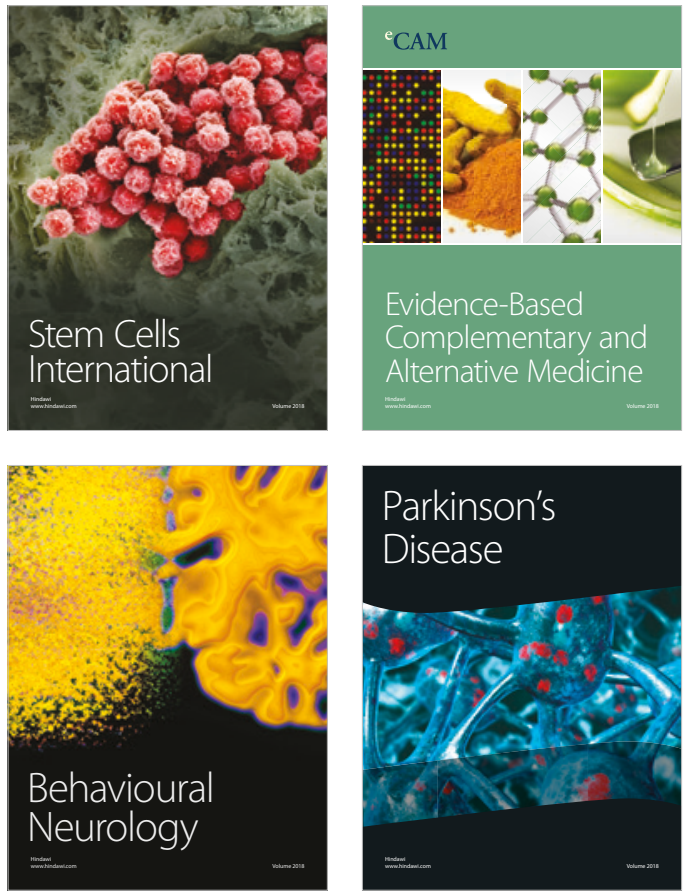

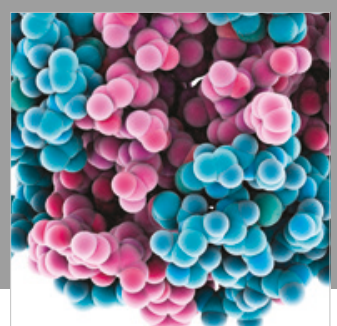

ournal of

Diabetes Research

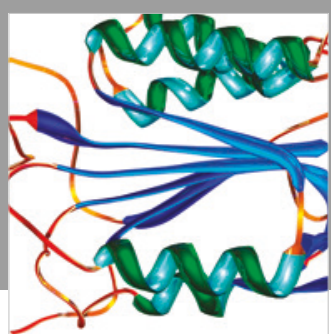

Disease Markers
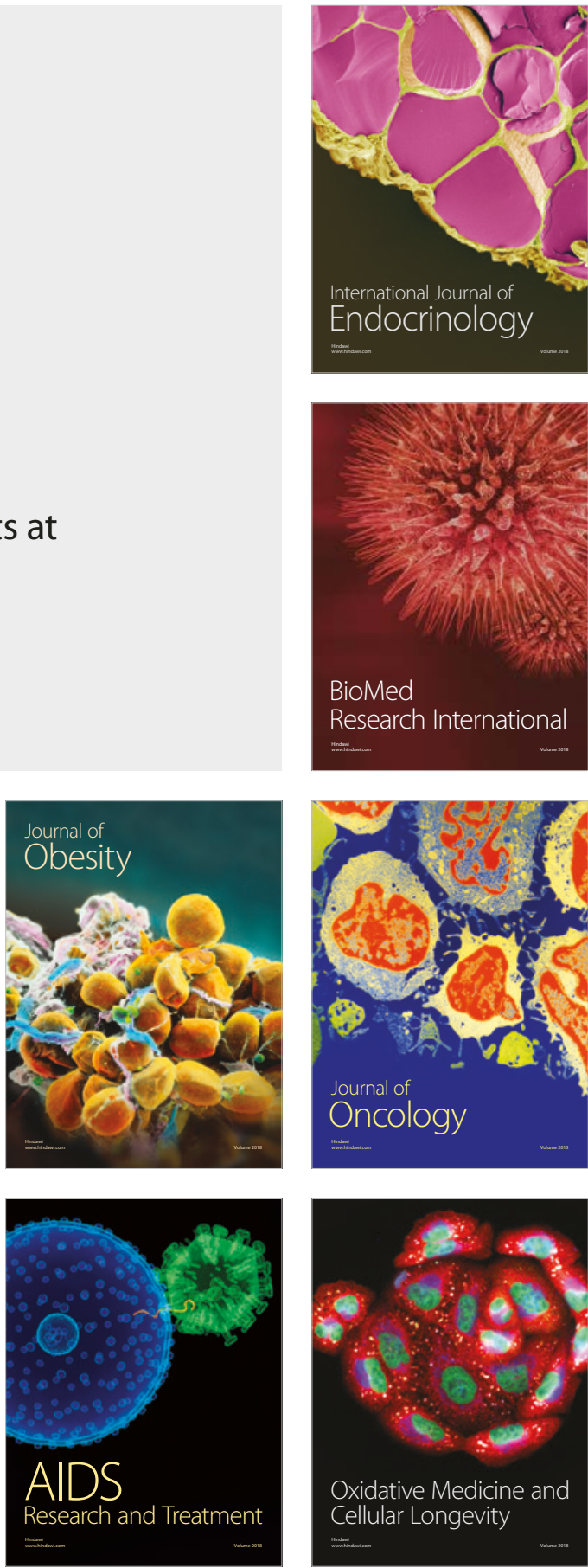